\title{
農業政策の展開と集落営農
}

小 林 哲 郎

\section{The Development of Agricultural Policy and Group Farming}

\author{
Tetsuo Kobayashi (Toyama Prefectural University)
}

\begin{abstract}
Thirty years after the Agricultural Basic Law was instituted, nurturing viable farms was a main policy goal has not progressed in agriculture based on the use of land, while part-time farming and sprawl have been widespread. Also, the overproduction problem of rice is still unsolved. The shortage of labor force and aging farmers has caused the severe problem of business organization : the "NINAITE" problem.

It was not before 1980 that policies nurturing group farming have attracted considerable attention in many rice-producing regions to break a deadlock in the severe recession phase of paddy field agriculture. Lately, the policies can be considered as important ones activate agriculture and farm villages.

The characteristic of group farming is the
\end{abstract}

\section{1.はじめに}

現在, 水田地带の多くでは兼業化と混住化, 農業労 働力の高㱓化がますます強まり, 農村部で農家は少数 派になってしまい, 不耕作地が増大しつつある.一方, 米の過剰問題が依然として解決せず，転作を余儀なく しているのに加えて食管見直し，米価の值下げ，米の 輸入自由化等々, 水田農業を取り巻く環境は一段之厳 しさを増してきている.

こうした困難な状況の中で, 農家個々では解決しえ ない営農上の諸課題について，集落等を一つのまとま りの単位とし, 集落の合意に基づく調整機能を活用 し，地域農業の再編成を図る農業生産の組織化の方向 をここでは "集落営農” と呼ぶことにする.

本稿では，まず，乙うした集落営農・地域農業の組 織化の背景を基本法農政の展開を通して概観し，とり わけ 80 年代の構造政策との関連で，その位置付けと方 向を検討する ${ }^{1}$. 第 2 亿, 80 年代に入ってより, 農協 が系統組織の総力をあげて取り組んだ農業振興方策を 跡付け, そこでの地域営農集団・集落営農の座標を明 mutual consent based on meeting at a territorial bond such as a village. There are five policy aims of group farming as follows.

(1) Accumulate farmland to use as a whole.

(2) Make efficient use of labor, machinery, and facilities.

(3) Nurture "highly productive production units.

(4) Construct a regional farming system makes it possible to cut cost.

(5) Overcome the severe "NINAITE" problem in a whole region.

But there are some unsolved problems in the development of group farming. For example, it is not easy to reach mutual agreement. In general, effects of group farming takes long time to be discovered.

らかにする．以上を踏まえて第 3 亿は，北陸・富山県 における集落営農組織化の動向・新局面を検討し，地 域農業の地域ぐるみによる再編方向を展望する.

\section{2. 基本法農政の展開と地域農業の組織化}

\section{（1）農業白書にみる農基法30年}

昭和 36 年に制定された農業基本法に基づいて，第 1 回目の農業白書の報告が行われてから, 平成 2 年度農 業白書はちょうど 30 回目になる. この 2 年度白書（全 4 章) は，その第 1 章「国民経済の発展と食料・農業 一 30 年間を振り返って」において，基本法農政の30 年を概括している.

すなわち，農業基本法が揭げた目標・理念は，高度 経済成長下で他産業との格差是正を図ることであった が，工業等と比へ，生産性の面でも所得の面でも格差 は広がっており，目標は達成されていないという分析 である．以下，本稿の課題とのかかわりで農業構造の 改善，地域農業の再編等を中心に，2 年度白書をみて おきたい2). 
1）米の生産調整と水田農業の再編

46年度加ら本格的開始されている米の生 産 調整 は, 生産調整量が拡大するなかで水田利用再編対策以 降目標を達成し，この過程で転作を契機汇経営の複合 化や, 転作田の団地化や地域輪作農法（田畑輪換及び ブロックローテーション) が広がっている.

この間, 生産調整対策の内容も当初の米から他の作 目への転換を重視したものから，構造政策を重視し， 水田農業の体質強化を主眼とするすのへと変わってお り,さらに, 当初の行政主導加, 最近では, 生産者 -生産者団体の主体的取り組みが進展し, 行政と生産 者団体が一体之なって転作の推進が図られている.

水田は我が国農業の基礎を成すむのであり，今後と あ米需給の過剩が見込まれている状沉のもとで，地域 の実情に応じ，稲作と転作とを有機的に結び付け，水 田のあつ高い生産力を最大限に発揮させつつ生産性の 高い水田農業の確立が求められている。一方, 稲作の 生産構造は大規模な階 層 の生 産シェアの拡大がみら れ，また近年では，生産の組織化や農作業の受委託等 の動きが活発となっている.

しかし, 都府県の経営耕地規模 3 ha以上層の水稲作 付農家の戸数シェアはわずか $3.6 \%$, 作付面積シェア は15.7\%にとどまっており，今後，稲作の体質強化を 図っていくためには，経営規模の拡大や生産の組織化 の動きを加速するととが重要である，と分析してい る.

2）土地利用型農業の規模拡大と生産組織等の展開

このように，都府県において農地の集積による規模 拡大が全体として十分に進展しなかった要因の一つと して，農地の価格高騰と資産的保有傾向の強まりがあ り，農地制度の影響が指摘された。

このため，55年の「農用地利用増進法」の制定等， 数次にわたる改善がなされてきており，規模拡大を志 向する農家に対し利用権設定を中心とした農地集積を 促した. その結果, 耕作目的の農地の権利移動面積は 50 年の約 5 万ha から元年には約 10 万haに達し，その内 訳をみると利用権設定等の貸借によるものの割合が， ての間に $11 \%$ 加 $62 \%$ 亿高まっており, 農地の流動化 の中心は所有権の移転加貸借に変化してきている.

一方, 高龄化, 兼業農家む含めた生産組織化の取り 組みが近年盛んとなっており，てれらの農業生産組織 等が，地域ぐるみでの集団転作や農業機械・施設の共 同利用等を通じた地域農業の組織化の推進 主 体とし て，また規模拡大を志向する個別経営にとって実質的
な規模拡大を四る場として，重要な役割を果たしてい る. 現在，乙れら農業生産組織に参加している農家は 約 40 万戸で，うち 5 万 3 千戸は農作業を担うオペレー ターとして活動している. また, 近年では, これら受 託組織, 協業経営組織への参加農家が增えていると分 析している.

以上の動向から, 今後, 地域農業のリーダーとなる 中核的農家や生産組織, 農業サービス事業体等に農地 や農作業を集積させるなど，地域の実情に応じた多様 な担い手の育成・確保を図っていく必要がある．乙の 場合, 市町村や農協等の関連する機関・団体が一体之 なった農業構造改善の取り組みを展開することによ り, 担い手を支援し, 地域全体として生産性が高く, 市場適応力の強い農業を確立していくととが重要であ るとしている.

3）環境条件の変化への対応

農業構造の改善をめぐる今後の重要課題として, 白 書が指摘している点は次のとおりである.

第 1 亿は, 兼業化の進展や農業労働力の高齢化が急 速に進むなか，農業の担い手か激減しており，土地利 用型農業の飛躍的な生産性向上や多様な消費者ニーズ への適切な対応などの課題に対し, 従来の家族農業経 営に加えて，乙の枠組みを越えた生産対応子必要とな ってきており，組織や集落等の機能をより一層活用し た，地域的広がりをあち持続的・安定的発展が可能な 生産システムや経営体を育成し, 地域農業全体として の経営改善・振興を図っていくことが不可欠となって いる.

第 2 には，地球環境問題が顕在化するなかで，農業 の果たすべき役割とその評価につき改めて検討する必 要が生じたてとである. 我が国農業, 特に水田農業の 屯つ国土・環境の保全という機能については，より認 識を深める必要があるとともに，国民的合意のあと で, 生産性の向上視点に加え, 上り環境や人間之調和 した農業のあり方についての検討が進められるべきで あろう.

そして第 3 は，乙のほかにも情操と創造性のかん 養，居住の場の提供等の多面的な機能を有する我が国 農業・農村が，今後とも経済社会の安定的な基盤とし て一層の発展を図るためには，国民の合意と支援を得 つつ, こうした環境変化に対応して, 制度・施策のあ り方について中長期的展望に立って, 積極的かつ総合 的に見直しを行っていくことが重要である，と述べて いる. 


\section{（2）構造政策の推進と地域主義}

構造政策の発端は，いうまでもなく農業基本法の制 定にあり, 国の農政の基本目標（生産性の向上之所得 の増大）を達成するための施策である，構造政策はこ のため, 農業経営規模の拡大, 農地の集団化, 機械化 などによる農地保有の合理化と農業経営の近代化を図 るととであり，その中心的課題が「自立経営の育成と 協業の助長」であった.

農基法における構造政策の位置づけ, 必要な事業, 施策の範囲はきわめて広いものであるが，望ましい農 業構造を実現するのに必要な施策（農地の流動化, 土 地基盤の整備, 資本装備の充実, 優秀な農業従事者の 確保，技術の向上など）について，その展開過程を概 観しておてう3.

1 次, 2 次, 新農構に至る農業構造改善事業の系譜 のなかで，いわゆる「1次構」の特色は, 農業構造の 改善が進むような条件整備を行うことにあった.すな わち，30 a 区画の固場整備, トラクター, コンバイン などの大型機械導入, ライスセンター, 選果場などの 大型集出荷施設の設置等を通じて, 農業構造の改善に 資するあのであった.

そして, 農林省をあげての検討を経た昭和 42 年 8 月 の「構造政策の基本方針」を契機として新たな展開を みる，そのなかで注目すべきてとは，農産物の安定供 給・農業生産の維持増大という生産力増強の視点が加 わり, “農業生産の中核的な担い手としての自立経営” という考え方が登場しているととである.

また，兼業農家を含め，地域的な配慮をしながら， 例えば協業等の “集団的生産組織”を育成助長する等 の施策を工夫する必要があると, 兼業問題にふれてい るととにあ特徴がある.

また，44年発足のいわゆる $\ulcorner 2$ 次構」の特色は，自 立経営等, 規模の大きく生産性の高い農業経営を育成 し, これらの経営が地域農業の中核的な地位を占める 農業構造の実現を四るととを目標とし，自立経営等 （自立経営に準ずる協業経営，自立経営を目標とする 農業者を中核とする協業組織を含む) の地域農業生産 に占める割合を増加させることを重要な計画の要件と したことにある。

全体としてみれば，2次構は自立経営の育成に，よ り直接に取り組もうとした意図がみられる. 以上のほ かに，46年制定の「農振法」は, 地域における農業構 造改善の総合的計画的な推進という考え方を明確に打 ち出す契機となったとされている.
農業生産の中核的担い手の育成確保，あるいは中核 農家の育成之いう政策目標が揭げられるのが昭和50年 代の農政の特徴であり，乙の時期から今日にかけての 構造政策の展開としては, 農用地利用增進事業制度の 創設（50年農振法改正）之新農業構造改善事業の実施 （54年）が代表としてあげられる.

農用地利用増進事業の基礎となっている考え方は， “地域における集団的な農地の貸し借りを行う”こと であり，乙れが52年度発足の地域農政特別対策事業に おける地域農政推進のための重要な手法とされてい る. さらに, 農用地高度利用促進事業（54年度発足） によって農地流動化施策の主体的地位を占め, 相当面 積の利用権設定の実績をあげている。

こうして,「新農構」は農村地域の構造改善事業と して仕組まれており，地域内の広範な農家層を包摂し た農業の組織化を通じて，農業生産の担い手の育成確 保, 農用地の利用管理の適正化及び地域農業の複合化 を図り，高度で安定的な農業生産力を有する地域に整 備し，あわせて環境条件の整備を図ることを目標とし ている，事業としては，農業組織化の促進のための構 造改善推進事業を新設し，土地基盤整備，農業近代化 施設整備及び集落環境施設整備を行うとしているが,

“おおむね 2,3 集落の区域”で行う地区再編事業に おいて，作付栽培協定の締結と実践を要件としている 点に注目できる.

ここには，新しい地域主義といわれる地域単位の農 業構造改善推進の考え方が示されており, 前記の地域 農政特対事業に端を発した “地域における協議, 調整 及び推進の活動”を重視する傾向にも注目できる。ま た, 農用地の権利移動, 有効利用については, “集落等 の地区における，農業者の合意を推進するこどとし ている.

このように, 構造政策の展開過程をたどると, 昭和 50年代における地域主義的な方向が影著にみられ, 農 業生産の中核的な担い手あるいは中核䢅家といういい 方む，“地域における中核”という意味をむつに至っ てきたといえる.

\section{（3）農用地利用増進法と地域農業集団}

55 年制定の農用地利用增進法は, 上記のような地域 主義的な構造政策の流れのなかでつくられた法律であ り, 賃貸借を中心として経営規模を拡大し, 生産性の 向上を図ろうとしている中核農家に農用地を利用集積 させるととを意四している。

また，ての法律によって市町村が行うとととされて 
いる農用地利用増進事業は，地域農業者の理解と合意 を醸成しつつ, 農業委員会, 農業協同組合等と協力し て, (1)地域農業の組織化を通じて土地, 労働力, 機械 施設，副産物等地域の農業諸資源の有効利用により， 地域農業の総体としての生産力向上を図りつつ, (2)農 業生産力発展の原動力となる農業経営を地域農業のな かで育成・定着させていくことを称らいとしている.

そして，乙の法律に規定されている農用地利用改善 団体（地権者の 3 分の 2 以上が参加し，一定の規約等 をむつ）は，作付地の集団化や農作業の共同化を実践 することが期待されている，乙のため，集落農家の全 員が合意に達するまで話し合いを行うなど, 農地の所 有と利用を分離し，いずれの関係者も損をしないよう な調整に多くのエネルギーを投入している。つまり， この「改善団体」に期待しているととは，「ムラの論 理」を出発点として農用地の有効利用方策についての 合意を形成していくととにある.

この農用地利用改善団体は，「ムラの論理」による 調整機能が発揮できる範囲でつくられるととから, そ れはまず集落であり，せいぜい数集落でつくられると とが予定されていた．しかし，その形成はまったく遅 々としているという状況であった。

こうした現実が，実質的には同じ機能を果たす地域 農業集団の “活動促進”を強調させるととになったと されている4).

“地域農業集団”という言葉（農政用語）が初めて 登場するのは 57 年 8 月, 農政審答申「80年代の農政の 基本方向」の推進について一一健康的で豊汃な食生活 の保障と生産性の高い農業の穾現をめざして一一な かであり 8 項目のうちの 4 番目, “地域農業の組織化” のキーワードとして使われている.

すなわち，「地域農業全体としての生産性向上を実 現するためには，作物の選定，作付けの団地化，地力 の維持, 農地の権利関係や利用関係の調整, 農作業や 機械利用の効率化, 副産物之の他地域資源の活用等の 地域における諸活動が，農業者の話合い之協力によっ て自主的かつ有機的に行われるような仕組み一いわ ゆる地域農業の組織化一一泌要である.

このため, 集落等を基礎とし，中核農家や兼業農家 を含め, 地域の土地利用や農作業活動についての話合 いや合意形成，共同活動を行う地域農業集団の活動を 促進することが適当である」

「また，乙の地域農業集団は，農用地利用增進法に 基づく農用地利用改善団体と同様の機能を有するとと
から，てれを同団体として青成することが考えられよ う、なお, 地域農業集団は, 地域の諎条件に応じて様 々な態様をとるむのと考えられるが，土地・水利用の 一体性，集落等の地縁組織との関係を考虑すれば，お おむね 1 ないし数集落程度をその区域とし，区域内の 農家, 生産組織, 農事組合法人等を構成員として形成 していくことが適当と考えられる」

すなわち，地域農業集団の育成に当たっては，兼業 農家等を含む地域としてのまとまりの中で, 自分達の 土地は自分達で守り, 有効に利用していくという, い わば「ムラの論理」を出発点として農用地の有效利用 方策についての合意を形成していくことが重要である と述べている5.

ここに, “集落営農" の原点あるいは出発点を見出 せるのである.

\section{3. 系統農協の農業振興方策}

\section{（1）1980年代の農業振興方策の経緯}

前節では, 基本法農政の目標は農業と他産業との格 差是正に置かれ，所得的に均衡できる自立経営を育成 することだった．しかし，自立経営の形成よりは，機 械・施設を中心とした組織化だったとと，そして，い まや地域農業の組織化は農用地利用までむ取り込むて とが求められてきているととをみてきた.

系統農協屯農協として, 農業・農村の変容にいかに 対処すべきか，変化する経済環境のなかで組合員農家 の営農を発展させ，生活を守る方策のいかんを問い続 け, 農協があつべき農業振興方策を常に求めていた。 こうした取り組みを第 15 回大会以降についてみると, およそ次のとおりである6 ${ }^{6}$.

系統農協は，1980年代を見通しつつ，昭和54年の第 15回全国農協大会において, 『1980 年代日本農業の課 題と農協の対策』を決議し, 地域農業振與計画の樹立 ・実行によって, 地域農業の再編に取り組んできた. すなわち, 農産物の供給過剩基調を背景にして「地域 農業の再編・確立」を 80 年代をつうじた基本目標とし て揭げ, てれを具体化するため, 地域農業振興計画の 策定・実践を市町村農協から積み上げによる全国生産 ・眅売計画の策定による需給調整を提起し, この取り 組みを進めてきたのである.

また，農政審答申(『80年代の農政の基本方向』)が 出された同じ57年10月に開かれた第16回大会決議 の 『日本農業の展望之農協の農業振興方策』では, 『80年 代対策』を引き継ざつつ, 課題への取り組みを一層具 
体化し，とくに土地利用型農業強化の方策を提起し， 地域営農団の育成・強化, 稲作コス卜低隇を農協運動 として加え，実践に努めてきた。

さらに，60年の第17回大会決議の『1980年代後期に おける農業・農村振興方策』では，先の『80年代対策』 『農業振興方策』を補完しつつ, 重点課題として, (1) 良質・低コスト・計画生産の推進，(2)地域諸資源をい かした農業生産体制の確立, (3)活力ある農村社会の建 設，を設定して地域農業振興計画の質的充実を図りつ つ, 地域の労働力や生産資源の組織的利用対策, 地域 営農集団育成, 低コスト対策の一層の推進, 地域特産 加工の開発振興等を四ることとしたのである.

\section{(2) 地域営農集団の育成}

このように『農業振興方策』は, 地域農業振興計画 を方向付ける性格をむっているが，農協の “地域営農 集団” の構想はこの『方策』の第 2 章の 3 「新しい土 地利用秩序と農業生産組織の確立」という節の(2)「経 営機能の革新と農業生産組織によるコスト引き下げ」 の項のウ「地域営農集団の育成と地域農業の確立」と いうなかにでてくる.

「労働力, 機械・施設, 副産物等の農業生産諸資源 を地域を単位として，有効利用するととについて，す でに全国各地に先駆的事例として多くの経験が蓄積さ れている.

しかし, 水田転作面積の拡大や労働力の劣弱化の屯 とで，土地利用の組織化，つまり集団的土地利用秩序 の形成を基軸に，地域の農業生産諸資源の有効利用の 体系を組み立てるととへの取り組みはいまだ不十分で あり, このととの実践が農業生産力の活性化のための 今日的課題となっている.

したがって，土地利用を中心とする組織化の推進力 として，地域営農集団を育成することが必要である.

地域営農集団は, 農業生産組織の 1 つの新しい形態 であり, 地域ぐるみの農家の合意を基本とし, 農作業 などへの参加を通じて土地利用と, 地域の農業生産諸 資源の有効利用を四る仕組みである，乙の仕組みのも とで，専従者のいる個別農家やオペレーターなどのグ ループを中心に参加農家が役割を分担し，栽培管理や 機械利用を行なうことになる。

てのととによって，専従者のいない経営も維持さ れ，専従者のいる経営もその能力を十分に発揮するこ とが可能となり, 将来の地域農業を担う人材を育成・ 蓄積してゆくことができる7)」と述べており，地域営 農集団は集団的土地利用秩序（団地的・組織的土地利
用及び土地利用調整）の形成を重視する生産組織の 1 つであると理解できる.

さらに，地域営農集団という組織は「地域内の全農 家を包み込んだあのとして形成されるととが望まし い．そして，集団の機関としては，合意形成・意思決 定を行う総会及び具体的な農業生産活動を担う実行機 関が必要である」といい,「とのため,その推進を担う リーダーを見出し，地域営農集団の育成に積極的に取 り組む」とし，「とくに，地域農業振興計画の策定 実践との関連において，農協支所または集落における 農業生産活動の中心的な担い手として, 地域営農集団 を位置づける8)」と述べている。

地域営農団はこうした内容とねらいをあつあのであ り，国の地域農業集団之同様のあのであるが9 ，農協 あるいは集落はただ単に “農用地などの利用調整機能 をあつ組織” としてだけではなく，同時に “生産の機 能的な面であ結合した組織” であると踏み込んで理解 する必要がある。

そして周知のように，国と農協系統組織は，一体之 なって，地域におりる話し合いと合意形成により，農 用地に係る権利の設定・移転等による中核的担い手の 経営規模の拡大, 農用地の面的利用の集積, 地力の維 持 - 増進, 農用地の効率的利用等の “集団的土地利用 調整”に取り組む集団の育成を推進してきているとて ろである.

\section{(3) 農業振興方策の実践 ${ }^{10)}$}

1）地域農業振興計画策定・実践運動

この計画策定については，米以外の作目への転換 • 定着化や集団的な農用地利用をめざして，55年以降， 3 次にわたる「策定・実践運動」を展開してきた.

62年度における全国の計画策定農協は2, 521 農協(策 定率 $62 \%$ ）となっているが，乙れは59年度から56農協 （3\%）増加したにとどまっている.

また，その内容が主要作物の生産・販売の数量的計 画を中心とするすのが多く，乙の計画の実現を裏付け る農用地の利用調整や担い手の育成など，地域農業の 構造の再編についての重要性は認識されつつあるが, これを内容とした計画を備えたものは少ないと分析し ている.

2）地域営農集団育成・強化運動

この「㕕成・強化運動」は58年度より実施し，61年 度加ら第 2 次運動」を展開し, 地域営農集団による 耕地面積のシェア $50 \% ， 1$ 農協当たり平均 10 集団の育 成を目標として推進してきている. 
63年現在, 設立されている地域営農集団の数は約 2 万 7 千で, 集団の設立ペースは遅々としている.

62年より水田農業確立対策事業の実施に伴い増加傾 向をみせているが, 全農協に対する割合でみると, 地 域営農集団育成・強化運動に取り組んでいる農協の割 合は 62 年度で $36 \%, 59$ 年度から $3 \%$ しか増加していな い. しかも, 地域営農集団による耕地面積シェアが50 \%以上の農協は $13 \%$ にすぎず，目標を大きく下回って いる状況である.

3）地域農業の構造再編による低コストの追求

21世紀にかけて，65歳未満の男子専従者がいない集 落が都府県で 4 割に達すると見込まれるなど農業労働 力の高齢化や兼業化によって, 今後一層, 地域農業の 生産が後退し, 農用地の荒廃が進行するものと予想さ れている.

このため, 農協は「隣保共助」にあとづき, 地域単 位に農用地所有者のすべてを含んだ合意形成によって 農用地の利用調整を行い, 低コスト農業を可能とする 農場的な生産体制を構築する地域システムを創り出す こととしている.

このととによって, 所有する農用地を維持管理した いという高龄農家や第 2 種兼業農家の要望に応えてい く一方, そのなかで労働力の条件に応じて高㱓者, 婦 人，兼業農家等を含めた作業編成を行う．また，その 際, 意欲のある担い手農業者・グループに活躍の場を 与えつつ, 将来の地域農業の担い手の確保を図ってい く,というあのである.

21世紀に向けて，系統農協は，農業集落の過半で地 域営農集団の組織化を推進し，また，農協の農用地利 用調整機能を積極的に展開することによって, 全国の 水田の 3 分の 2 以上を中核的農家 - 集団を中心とした “農協の農用地利用調整システム”でカバーするよ う，その総力をあげて取り組むとととしているのであ る.

\section{4. 北陸・富山県における集落営農の展開 ${ }^{11)}$}

\section{（1）北陸における集落営農への取り組み}

北陸地域では，集落ぐるみ（集落の範囲またはそれ 以上にわたり組織化されたもので, 当該集落農家のお おむね 2 分の 1 以上あるいは 15 戸以上が参加したす の）で, 農業生産の低コスト化に向けて組織化してい る集落営農は, 昭和 58 年に約 1,100 組織であったもの が，平成元年には約 2,800 組織となり，大幅な伸び (2.5倍強) を示している12).
このため北陸農政局では，平成元年 6 月現在の管内 における集落営農の実態調査を実施し，検討を加え た。調查対象集落は，水稲または転作作物（麦・大豆， 飼料作物及びソバ) にかかわる全作業・部分作業また は土地利用（転作作物の集団化栽培）について，参加 農家の合意に基づき組織的に取り組んだ集落とした. その調査結果の概要は次のとおりである ${ }^{13}$.

(1)集落営農への取り組みの動機は，56年度以降の水田 利用再編・I期対策における「団地化加算金」や市 町村の誘導等を契機とするものが $80 \%$ 占めてお り，営農形態別には，「転作作物のみ」の集落営農 が75\%を占めている.

(2)集落営農の担い手形態には，(a)中核的農家型，(b)生 産組合役員型, (c)全農家参加型, (d)オペレーターグ ループ型等があり，(a)・(b)の両タイプで約70\%を占 めている.

(3)集落営農の運営状況は, 参加農家談合, 農地・機械 ・施設等利用計画，運営規約制定など多岐にわた り，農地利用や作業受委託・出役等の調整状況をみ ると，何らかの形で調整が行われている組織が $44 \%$ を占めている.

(4)集落営農の70\%がコスト低減のメリットを感じてい るが,「従来と変わらない」や世話役の負担増など 「効果少なく問題が多い」あそれぞれ20\%ある.

(5)21世紀へ向けての地域農業における営農形態の将来 展望についてみると，担い手「グループを育成して 経営をまかす」が37\%で最む多く，次いで「農協が 中心的役割を果たす」 $20 \%$ ，「全農家が参加する組

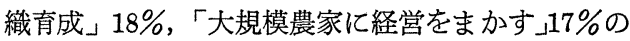
順となっている.

なお，県別の特徵をみると，富山県では稲作を含め た集落営農組織化が $47 \%$ 占めるのに対し，石川県， 福井県はそれぞれ $18 \% ， 14 \%$ と少なく，転作作物を中 心とした組織化が主流となっている．新潟県は北陸平 均の $25 \%$ に近い $28 \%$ と中間的である.また，集落営農 の将来展望は，「グループを育成して経営をまかす」が 平均 $37 \%$ で各県とも多いが，特に石川 $42 \%$ ，新潟 $39 \%$ に対し，富山と福井はそれぞれ $21 \% ， 23 \%$ 少ない. そして，富山県では「全農家が参加する組織育成」が $29 \%$ ，福井県では「農協が中心的役割を果たす」が23 \%と多い. こうした相対的な差は，各県における土地 基盤の整備水準や兼業の深化等に起因するすのと考え られる.

各県の取り組みを概観すると（富山県は次節で述べ 
る)，新潟県では，63年11月に県農協大会で決議した 「地域営農集団を核とした地域農業の確立」に向けて, 重点課題として地域営農集団を中心とする農業構造の 再編と稲作の生産コスト低減（30\%ダウン）を目標に 揭げ, 「地域営農集団育成強化運動方針」を策定し, 以来, 本格的に“集団の育成・強化”に取り組んでき ている.また，そのために全 8 章構成の『手引き』を 作成し, 地域営農集団の形成に向けての考え方, 具体 的な組織化の手順, 集団の活動実態や経営管理, 参考 資料等が 296 頁にわたって詳細に解説されている ${ }^{14}$.

石川県でも，63年 7 月に「地域農業活性化推進事業 実施要領を策定し，21世紀に向けて本格的に「集落農 業」を推進しており，そのために，I 米生産・コスト ダウンへの挑戦, П地域農業の生産組織化及びリーダ 一育成対策，而関係制度の概要，の 3 部構成による全 106頁の『マニュアル』を刊行している ${ }^{15)}$.

福井県では, 福井県の農業・農村の未来を切り開く 「指針」を策定するため，62年 6 月に「 21 世紀農業展 望策定委員会」を設置した. 同委員会は, 地域の積極 的な連帯がなければ, 21世紀へ向けての農業の発展は 不可能であるとし, 集落全体の合意を得ながら「集落 営農生産体制」を構築する必要があるとし,「集落営農 モデル」を 4 種類（1)大規模農家中核，(2)大規模農家 - 兼業農家共存, (3)生産組織, (4)機械共同利用) 設定 している16).

\section{（2）富山県における集落営農の推進}

\section{1）集落営農体制の確立}

富山県において集落営農体制の確立を図る目的は, 各地域における兼業農家, 中核農家及び生産組織が, 個別では解決しえない営農上の課題について, 集落の 調整機能を活用し, その調整結果をもとに, 集団的土 地利用や機械・施設などの生産諸資源を集約し，生産 性の高い地域農業を実現しようとするととにある ${ }^{17}$.

零細兼業の稲単作農家が多数を占める富山県におい ては, 経営規模の拡大を志向する中核農家を中心に, 兼業農家むと屯に協力し合う，地域ぐるみによる「集 落営農組織」に再編成するという考えには早くから着 目し ${ }^{18)}$ ，すでに56年から「豊かな村づくりパイロット 事業」,57年から「集落営農組織化促進事業」ささに 61年からは「同実践事業」等々を県単独の事業として 実施してきている.

こうした成果等を踏まえ, 平成 2 年 8 月, 富山県・ 農協中央会・経済連・農業会議の 4 機関共催で,「集落 営農推進大会—豊かな村づくりをめざして」が開か
れ, 向こう 5 年間で県下約 3 千集落のすべてを組織化 するため，その憲章である「集落営農推進基本方針」 が確認・決議された.

そして, 3 年 7 月には関係機関が一丸となって, 農 協主導による「集落営農推進委員会」を設置し, 助成 事業として県は集落営農の「組織化実践」「生産体制 強化」の 2 事業, 中央会は「集落営農育成モデル事 業」を推進し，“点から面”への展開を積極的に図っ ている.

2）進捗状況と推進上の課題

平成 3 年 7 月策定の $「$ 富山県集落営農推 進基 本 計 画」によると, 平成 3 年から 7 月までの 5 年間に, 水 稲作にかかわる集落営農体制づくりに関して，3 年の 現状 831 集落（計画対象は県下の 2,810 集落)，29.5\% を 7 年の目標年次には 1,417 集落, $50.4 \%$ ま 高め る. 従来の個別経営型の集落は 1,266 集落, $45.1 \%$ 加 ら 653 集落, $23.2 \%$ 亿低下するという基本方向を揭げ ている.

このため, 1 年後の 4 年 7 月までに, 県下の全 51 農 協（本所段階で $2 つ の$ 信用農協を除く）において「集 落営農推進協議会」を設置するとともに, 支所段階 （265支所）においても同様に設置するよう努めるて とが推進目標とされている. 3 年度末の進捗状況はそ れぞれ31農協・60.8\%，147支所・55.5\%であるが, 集 落段階では，そのための「推進員」が設置された集落 は 680 集落で, 進捗率が $24.2 \%$ ときわめて低い.

また, 3 年度末現在, 農協の地域農業振興計画（営 農ビジョン) の策定状況は, 本所段階18農協（期限切 れの 19 農協を除く)・ $35.3 \%$, 支所段階 140 支所・ 52.8 $\%$, 集落段階532集落・18.9\%であり, 『手引書』等で いうところの「集落営農計画樹立」が末端の集落まで は浸透していない状況にある.

一方， 3 年度に集落営農関連単独事業を実施した市 町村は12（全35市町村の34.3\%), 農 協では14（51農 協の $27.5 \%$ ）で何らかの支援（機械施設, 処分農機具, 推進活動費等の補助) が行われており, 県・市町村や 農協はそれなりの役割・機能を果たしていると評する ことあできる. しかし, 以上の進捗状況の限りではそ の効果はあまり発現していないといえよう.

そこで，集落営農推進上の課題之問題点に関する農 協の意向調査結果（対象は 24 農協で複数回答）をみる と,「集落リーダ一不足」が 13 農協で過半を占めてい る. 次いで多いのは,「中核農家などの担い手不足」 8 農協, 「農業者の営農意欲減退」5 農協, 「集落営農 
計画の策定困難（都市化，スプロール化，不透明感 等)」 4 農協, 「中核農家との調整が困難」 3 農協, 「國 場条件が不良」 2 農協などの順である. 最近の環境条 件の変化に鑑み, 大きな枠組みのなかで克服していか ねばならない難問ばかりである.

このため, 当面する重点推進事項は, (1)集落営農推 進支援システムの構築（農業機械利用再編, 簡易農業 経営診断等の開発・利用促進), (2)土地利用型農 業生 産組織の総点検 ( 500 組織以上の機能強化), (3)生産組 織の経理・経営指導等の強化, (4)集落リーダー研修の 実施等を行うこととしている. 関係機関が一丸となり 「農業団体が主体となって一元的な推進体制の下，県 下全域において集落営農体制か確立されるよう，その 推進を強化」(「委員会設置要領」第 1 条) していると ころである.

\section{5. むすび}

平成 2 年度農業白書の指摘を踏まえ, 農林水産省で は中・長期展望に立って,「新しい食料・農業・農村 政策」に関する施策体系を再構築するとととし，3 年 5 月, 省内に事務次官を長とする「検討本部」を設け, 4 年春の『とりまとめ』を目途に, 周知のように 6 項 目について検討を行っている.

その第 1 の検討項目「多様な担い手（農業経営体） の育成」の概要のなかで, 「従来の家族的経営によって は地域の農業生産を維持し得ない場合むあることか ら, 地域的広がりを持ち, 持続性, 安定性及び高い生 産性を持った経営体を創出していく可能性を探り, そ

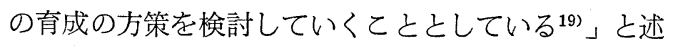
べている.

集落営農の展開方向は, この指摘に沿うむのであ り, 集落営農育成の目的は, 集落を一つのまとまり・ 合意形成の場として, (1)農用地の面的集積・高度利用 の確保, (2)農業生産効率・生産性の向上, (3)地域農業 生産システムの再構築, (4)新しい担い手の確保・形成, にある.また，集落営農の組織推進において，農協を はじめとする指導機関の役割が重要であるととをみて きた。

集落営農の展開は各県, それぞれの地域・集落がお かれた諸条件の違いによって多様性をむっている，集 団の活動内容は多岐にわたり, 多様化した構成員間で 困難な調整を要するととが多いため, 集落営農を育 て，集団組織を担っていくリーダーと，乙れを支える サブリーダー（あるいはフォローアー）の存在が重要
である.さらに, 集落営農の成果が発現するのには少 なくとも $3 \sim 5$ 年, あるいは10年といった長期を要す るなど，なお解決すべき難問がある.

そうではあるが，激しい後退的局面にある現下の農 業・農村の活性化を図る基本方向は，その地域・集落 における集団的土地利用を軸に，地域・集落ぐるみの 話し合いによる合意のなかで, 労働力や機珹・施設等 の地域農業諸資源の効率的・合理的利用を図っていく 施策は有効であるといえよう.

注 1) ここでの検討の枠組みは主として次の文献に依 拠している. (1)山本修編『農業政策の展開と現状』 家の光協会, 1988年(現代農業政策論第 2 巻), (2) 藤谷築次編『農業政策の課題と方向』家の光協会, 1988年 (同第 3 巻), (3)「どうする日本の農業一 論争：日本の農政」農山漁村文化協会, 1992年 3 月(『現代農業』臨時増刊)。

2）『平成 2 年度図説：農業白書』農林統計協会, 1991年.

3 ) 関谷俊作「農業構造政策の課題と展開」『農業 と経済』46-4，1980年，25～31頁.

4 ) 梶井功「地域農業 (営農) 集団の足跡と課題」 『1984年・日本農業年鑑』家の光協会, 1983年, (特集 II 所収, $70 \sim 96$ 頁).

5) 農林水産省構造改善局農政課「農用地利用増進 法・農地法改正法一問一答集」1980年, 117頁.

6 ）全国農業協同組合中央会 $\boldsymbol{r}_{21}$ 世紀を展望する農 協の基本戦略——国際化のなかでの日本農業の確 立と魅力ある地域社会の 創造—』1988年10月 (第18回全国農業協同組合大会議案).

7 ）全国農業協同組合中央会『日本農業の展望之農 協の農業振興方策』1982年, 44 45頁.

8 ）全国農業協同組合中央会『前掲』1982年, 58〜 59 頁.

9 ）全国農業会議所『地域農業集団育成の手引一 地域農業集団活動のねらいと進め方—』1983 年, 26頁.

10）全国農業協同組合中央会『前掲』1988年, 3 $4,16,27$ 頁.

11) 小林哲郎「集落営農組織化と展闒方向」（向井 三雄・矢尾板日出臣・小林哲郎編著『現代のシュ メ、問題：新たな生産と流通』農林統計協会, 1992年, $69 \sim 78$ 頁).

12）北陸農政局「平成 2 年度北陸農業情勢報告」 1991年, $51 \sim 59$ 頁。

13）北陸農政局「北陸における稲作を中心とする集 落営農の現状と意向」1990年, 1～2, 12頁. 
14）新潟県農業協同組合中央会『地域営農集団育成 の手引き』1988年 8 月.

15）石川県農林水産部『集落農業推進マニュアル』 1989年 1 月.

16）福井県『21世紀をめざして：福井型農 業の 展 開』1988年 (全 6 章, 86頁).

17）富山県農業水産部・富山県農業協同組合中央会 r集落営農指導新書：新しき時代への生き残り戦
略』1990年 3 月（全12章，429頁)，9１0頁.

18）小林哲郎編著『集落営農の手引一一富山県にお ける地域農業のすすめ方』富山県農業協同組合中 央会, 1985年 3 月.

19）高木勇樹「新しい食料・農業・農村政策に関す る検討の枠組みについて」『農業と経済』57-11, 1991年, 23頁.

（筆者：富山県立大学） 